\title{
Soberanías Convulsionadas: Polémicas Independentistas (El Redactor, Tucumán, 1816) ${ }^{1}$
}

\author{
Troubled Sovereignties. \\ Independence Controversies (The Editor, Tucumán 1816) \\ Soberanias Convulsionadas: \\ Polêmicas Independentistas (El Redactor, Tucumán, 1816)
}

\author{
Esteban De Gori ${ }^{2}$ \\ Universidad de Buenos Aires - Argentina \\ Grupo de Investigación ILAC \\ edegori@sociales.uba.ar
}

Recepción:29/10/2012

Evaluación: 19/07/2013

Aceptación: 15/05/2014

Artículo de Reflexión

RESUMEN

Este trabajo se interroga sobre los debates que los representantes de las diversas jurisdicciones de las Provincias Unidas del Río de la Plata desarrollaron en el proceso independentista, como en la construcción del orden posrevolucionario. En este sentido, nuestro propósito es presentar las polémicas políticas que se encuentran consignadas en el diario de sesiones $E l$ Redactor del Congreso independentista reunido en el año de 1816 en la ciudad de
Tucumán. Nuestra hipótesis de trabajo sostiene que estas pugnas están vinculadas, no solo a la efectividad de la representación y del ejercicio de poder; sino a aquellas orientadas por la voluntad de constituir una comunidad política que articule y cohesione una autoridad y un territorio frente a la guerra. Por tanto, podemos observar que un léxico republicano clásico -esgrimido por los diputados- pudo articularse con una propuesta monárquica moderada. Es decir,

1 Este trabajo es resultado del proyecto de investigación: Discursos Políticos de iollos Ilustrados en las Independencias Americanas (código SGI: 1128), avalado por el Consejo Superior de Investigaciones Científicas (CSIC) y la Universidad Pedagógica y Tecnológica de Colombia (UPTC). Esta investigación fue desarrollada por el grupo Ilustración en América Colonial (ILAC), reconocido y visible por Colciencias.

2 Doctor en Ciencias Sociales, Universidad de Buenos Aires (UBA). Investigador CONICET/IIGG. Profesor de la Facultad de Ciencias Sociales (UBA) y de la Universidad Nacional de San Martín. 
como dicho republicanismo - centralmente crítico de las facciones- logró encontrar amparo en la figura de un monarca y en la efectividad de sus modus operandi para detener la fragmentación territorial y política. Para fundamentar empíricamente nuestra propuesta, se han utilizado el diario de sesiones del Congreso (El Redactor), como documentos oficiales y actas de guerra. Nuestro marco metodológico está provisto por los aportes renovados de la historia política y por aquellos que nos brinda la perspectiva comprensivista $y$ posestructuralista para el análisis de los discursos políticos. Esto nos permitirá construir los sentidos y significados de los lenguajes que atraviesan las polémicas posrevolucionarias.

Palabras clave: Revista Historia de la Educación Latinoamericana, Redactor, Tucumán.

\section{ABSTRACT}

This work wonders about the debates that leaders of differentjurisdictions of the United Provinces of the Río de la Plata developed during the independence process, as in the construction of the after revolutionary order. In this sense, our purpose is to present the political controversies that are registered in the journal, The Editor - the independence Congress met in the year 1816 in the city of Tucuman. Our hypothesis of work supports that these battles are linked, not only to the effectiveness of the representation and of the exercise of power; but also to those faced by the will of constituting a political community that it articulates and cohesione an authority and a territory opposite to the war. Therefore, we can observe that a republican classic lexicon - used by the deputies could be articulated by a monarchical moderate proposal. It means -the critical republicanism of the factions managed to find shelter in the figure of a monarch and the effectiveness of their modus operandi to stop territorial and political fragmentation. To empirically substantiate our proposal, we have used the daily session of Congress (the Editor), as official documents and acts of war. Our methodological frame is provided by the renewed contributions of the political history and by those that offer to us the understanding ans structuralist perspective for the analysis of the political speeches. This will allow us to construct the meanings of the languages that cross the postrevolutionary polemics.

Key words: Journal History of the LatinAmerican Education, Editor, Tucuman.

\section{RESUMO}

Este trabalho problematiza os debates que os representantes das diversas jurisdições das Províncias Unidas do Rio da Prata desenvolveram, tanto no processo independentista como na construção da ordem pós-revolucionária. Neste sentido, nosso objetivo é apresentar as controvérsias políticas que são inseridos na sessão $\log$ da independência Colunista Congresso no ano de 1816 na cidade de Tucumán. Nossa hipótese de trabalho argumenta que essas lutas não são ligadas apenas à eficácia da representação e do exercício do poder; mas para aqueles guiados pelo desejo de estabelecer uma comunidade política que articula e autoridade cohesione e território contra a guerra. Portanto, podemos ver que um clássico -esgrimido léxico republicano por deputados, poderia articular uma proposta monarquista moderado. Isto é, como dito republicanismo - centralmente crítico das facções - logrou encontrar amparo na figura de um monarca e na efetividade de seu modus operandi para deter a fragmentação territorial e política. Para fundamentar empiricamente nossa proposta, foi utilizado o diário de sessões do Congresso (El Redactor), além de documentos oficiais e atas de guerra. Nosso marco metodológico está provido pelas contribuições renovadas da história política e por aqueles que nos brinda a perspectiva hermenêutica e pós-estruturalista para a análise dos discursos políticos. Isto nos permitirá construir os sentidos e significados das linguagens que atravessaram as polêmicas pós-revolucionárias.

Palavras-chave: Revista História da Educação Latino-americana, Redactor, Tucumán. 


\section{INTRODUCCIÓN}

El presente trabajo se interroga sobre las polémicas que los representantes de las diversas jurisdicciones de las Provincias Unidas del Río de la Plata ${ }^{3}$ desarrollaron en el proceso de declaración de independencia y estabilización de un orden político. Este texto posee como propósito analizar los debates y las preocupaciones políticas que se presentaron en el diario de sesiones El Redactor del Congreso independentista reunido en el año de 1816 en la ciudad de Tucumán.

A modo de hipótesis de trabajo, podemos plantear que las polémicas en torno a la independencia y al establecimiento de un orden común están atravesadas por las pugnas entre diversos imaginarios políticos de soberanía -como ya lo demostró Noemí Goldman —, por la preocupación sobre la efectividad de la representación y por los modos de ejercitar el poder. En este sentido, podemos indicar que dichas polémicas están guiadas por la voluntad de constituir una comunidad política que articule y cohesione una autoridad común y un territorio frente a la guerra.

En este proceso político que tiene entre sus resultados la declaración de la independencia, se planteó, a su vez, clausurar los "males de la revolución" abierta el 25 de mayo de 1810, estabilizar un orden común e instalar una autoridad legítima que obstaculice la fragmentación del territorio. Este conjunto de problemas prácticos impulsaron a los diputados a reflexionar sobre la indivisibilidad y pluralidad de la soberanía, acerca de la mutación de los sucesos políticos europeos, así como quién o qué órgano debía resumir y concentrar el poder político. Es decir, este contexto obligó a los miembros del Congreso y a los diversos actores políticos a presentar nuevas articulaciones discursivas. En este proceso, observaremos cómo un léxico republicano clásico pudo articularse ante la imposibilidad de los actores de suscitar una respuesta viable hasta ese momento, con una propuesta monárquica moderada; cómo dicho republicanismo centralmente crítico de las facciones (y de la pluralidad provincial) pudo encontrar amparo en la figura de un monarca y en la efectividad de sus modus operandi para detener la fragmentación territorial y política, y mostraremos la tensión entre un discurso de la representación ligada a la figura de diputado como "delegado de los territorios" y una representación "nacional" que reclamaba en el mismo momento de institución un momento autónomo para la toma de decisiones.

Por último, la utilización de El Redactor nos permite conocer y observar el conjunto de voces públicas interesadas en la construcción de un orden político, como la mirada de los propios redactores sobre los acontecimientos. En el contexto de soberanías convulsionadas, El Redactor nos habla de la travesía de la conflictividad e ingobernabilidad política iniciada en el mismo momento de la declaración de la independencia. El diario de sesiones se vuelve un testigo de las subjetividades, es decir, un "actor lexical" que da cuenta de los debates, pero que también asume una voluntad performativa. Para fundamentar nuestras reflexiones, utilizaremos los documentos del Congreso que están constituidos por las actas públicas del mismo, los cuales fueron reunidos en El Redactor del Congreso Nacional. También nos serviremos de algunas actas secretas, como así de diversos partes de guerra para comprender las variadas polémicas.

3 La denominación Provincias Unidas del Río de la Plata surge del Estatuto Provisional del Superior Gobierno de las Provincias Unidas del Río de la Plata a nombre del Sr. D. Fernando VII, el 22 de noviembre de 1811. Buenos Aires, Imprenta Niños Expósitos.

4 Noemí Goldman, “Formas de gobierno y opinión pública o la disputa por la aceptación de palabras, 1810-1827”, en La vida política en la Argentina del siglo XIX. Armas, votos y voces, comp Hilda Sabato y Alberto Lettieri (Buenos Aires: Fondo de Cultura Económica, 2003), 45-56. 
Nuestro punto de partida son los aportes renovados de la historia política que la universidad argentina e iberoamericana ha realizado en los últimos años. La metodología utilizada se sustenta en el análisis comprensivista de los discursos de los diferentes actores, lo cual nos permitirá construir desde su percepción y léxico un "lenguaje de la polémica" y de aquellas irresoluciones políticas que se abrieron con el proceso revolucionario de 1810.

\section{Culturas políticas, revolución y la búsqueda de un orden}

La dinámica de las revoluciones constituyó y abrió diversas posibilidades de acción en relación con la construcción de un orden político. La crisis no se resolvió de la misma manera en los variados territorios, es decir, se desarrolló contingencialmente y estuvo sujeta a disputas internas y jurisdiccionales. Por ejemplo, Paraguay -en su disputa con Buenos Aires— rápidamente declaró que se erigía como cuerpo soberano frente a la "ciudad cabecera" y logró construir unos años después un orden estable.

La crisis y la acción de los actores frente a esta construyeron contextos de posibilidad y tramas de acción que sirvieron en muchos casos para ajustar cuentas con las ciudades cabeceras o al interior de los mismos territorios. A su vez, la intensidad de la crisis y de sus circunstancias empujaron a los diversos actores a apropiarse de un conjunto de vocabularios políticos para fundamentar sus acciones. Como indica Mónica Quijada, en este proceso no existió un único imaginario que fundamentó la acción política de las élites, sino un conjunto de estos imaginarios que supusieron, "trasvases e influencias multidireccionales, de ideas, experiencias, redes de pensamiento y de poder". ${ }^{5}$

En el caso del Río de la Plata, la travesía iniciada por los actores para instituir una autoridad legítima asumiría ciertas singularidades. En 1810, la pugna con las autoridades regias impulsó a los actores rioplatenses a apelar a la retroversión de los derechos del Rey en la comunidad y a la potestas populi para instituir una Junta. Así, el 25 de mayo se había instituido la Junta Provisoria de Buenos Aires en nombre del Rey Fernando VII. Por lo tanto, mientras los insurgentes apelaban a la figura del pacto y de la soberanía del pueblo, las autoridades regias fundamentaban su jerarquía en los mandatos anteriores. Pero lo interesante de este proceso es que, pese a las tensiones entre regalistas y pactistas, ambas - a su manera- reivindicaban la figura del Rey y apelaban a ella para establecer sus argumentos y guiar sus acciones. Unos para instalar las juntas y otros para impugnarlas.

La crisis de autoridad y de gobernabilidad, provocada por la ausencia del Rey y luego por la disolución de la Junta Central, buscó ser suturada con la propuesta de autogobierno y la conformación de órganos colegiados. Para los insurgentes, ante la ausencia del monarca y el desconocimiento del Consejo de Regencia, lo único presente (empírico) era su fuente de autoridad: el Pueblo, la Ciudad o la Provincia. Como indicaba Mariano Moreno en la Gazeta de Buenos-Ayres: "un pueblo es pueblo, antes de darse a un Rey".

El autogobierno rioplatense, como respuesta política a la crisis monárquica, se estableció o se configuró, como otros tantos, bajo la apelación de la sujeción al Rey y de la conservación de sus derechos por un Pueblo que decidía y asumía guardarlos. Guardar sus derechos y administrarlos no sólo abría la posibilidad efectiva de autogobierno, sino la posibilidad de situar la vida y dinámica política en el interior mismo de la Ciudad y sus actores. De esta

$5 \quad$ Mónica Quijada, "La potestas populi: una revisión del pensamiento político hispánico y la Modernidad", en Entre la colonia y la república. Insurgencias, rebeliones y cultura política en América del Sur, comp. Beatriz Bragoni y Sara Mata (Buenos Aires: Prometeo, 2008), 32. 
manera, se apelaba y se inventaba a la ciudad o pueblo como un actor clave en la construcción de una comunidad política, situación que se iría extendiendo a todas las ciudades a medida que Buenos Aires las "liberase", pero que también en la medida que les exigiese la elección de diputados para establecer un nuevo ordenamiento.

El proceso político y los vocabularios pactistas y republicanos afirmaron a la Ciudad como príncipe para sí mismo (sibi princeps) y, por ende, como una autoridad que sólo tenía "deudas" con el actor o los actores que lo legitimaban y no con instituciones supraterritoriales (como podía el Consejo de Regencia) que pretendían, de alguna forma, imponer sus leyes y mandos. La Ciudad, al presentarse como una jurisdicción (iurisdictio) autónoma, fragmentaba el cuerpo de la monarquía y se multiplicaban los centros de poder político. Es decir, el escenario se develaba como un conjunto de soberanías que se autopercibían como actores con capacidad constituyente y de decisión.

Las élites insurgentes rioplatenses se instituyeron como representantes de ese Pueblo, ${ }^{6}$ asumieron de manera soberana los derechos regios y establecieron un gobierno autónomo. No debemos olvidar que en el mismo momento en que el Pueblo de Buenos Aires presentaba una petición con más de 400 firmas para formar un nuevo órgano gobernante, se consolidaba su representación política.

A partir de la instalación de la Junta y de la conformación de un contexto de guerra, la élite insurgente intentó construir su legitimidad, ampliar su base social y gobernar para el "público", reactualizando las memorias, las prácticas y los vocabularios que componían el universo lexical de la tradición constitucionalista y republicana. Había que republicanizar al Pueblo para convertirlo en defensor del nuevo gobierno y en un virtuoso miliciano. Es decir, había que utilizar las metáforas republicanas y los saberes para forjar y modelar una subjetividad que todavía estaba atravesada por "viejas preocupaciones". Ahora bien, no debemos olvidar que los partidarios del autogobierno también utilizaron algunas formas del ejercicio del mando que provenían de la cultura borbónica, sobre todo a la hora de imaginar cómo construir un orden desde la "ciudad cabecera".

La cultura política borbónica y la ruptura o impugnación de esta convivieron en el proceso de constitución de una élite revolucionaria, es decir, la ausencia de una garantía trascendente no "borraba de un plumazo" el complejo de imágenes y figuras sobre el poder político borbónico ni desarticulaba rápidamente los vínculos y símbolos de la obediencia política.

En el Río de la Plata, el autogobierno y su opción republicana se erigirían, en un principio, bajo el nombre del Rey. Esta situación constituiría una marca singular de este proceso. Entonces, los partidarios del autogobierno que intentaron legitimarse con vocablos republicanos (sobre todo los provistos por el republicanismo clásico), por un tiempo, amaron y reivindicaron al Rey. Lo amaron por la ineludible existencia de un ethos político borbónico y, además, lo amaron porque su figura seguía suscitando modelos de acción acerca de cómo organizar (o no) el poder y los territorios. El Rey no solo era la forma de un orden determinado, sino un modelo de soberanía, de ejercicio de poder y de encarnación del mismo.

En relación con los afectos hacia el mando, podemos advertir que el sentimentalismo regio también conviviría por un tiempo con el sentimentalismo cívico; es decir, ese sentimentalismo que buscaba enlazar a los hombres con su comunidad y a sus autoridades con el destino

6 Teniendo en cuenta el imaginario político hispanoamericano, la idea de Pueblo puede remitirse a la idea de Ciudad. 
y bienestar de la ciudad. Ahora bien, amar al Rey no significaba, mecánicamente, amar a aquellos funcionarios nombrados por su potestad. En este sentido, la ausencia del monarca en 1808 empujaría a la crisis misma del gobierno monárquico y del gobierno que ejercían sus funcionarios territoriales. En la confrontación entre los partidarios del autogobierno y aquellos que sostenían la organización política establecida por la Casa Borbón se esgrimieron distintas discursividades que los actores utilizaron para impugnar las acciones del contrincante. La disputa por quién actuaba en nombre del Rey y quién mejor lo representaba se desplegaba de manera significativa.

Las autoridades virreinales pretendían transformar a sus adversarios en actores antimonárquicos e infieles a la Corona. Para los partidarios del autogobierno, sólo el Pueblo podía ser el depositario de los derechos del Rey y elegir o legitimar a sus representantes. Por lo tanto, aquellas autoridades designadas por un Rey cautivo se transformaron en usurpadores del poder. Mientras que para estos funcionarios todo intento de autogobierno fue interpretado como un ataque al régimen monárquico. En su percepción, la radicalización que introducía el autogobierno "detonaba" su poder y la lógica cohesionadora que habían logrado los Borbones.

En este sentido, la crisis monárquica no sólo abría, develaba y potenciaba una disputa entre potestades y legitimidades, sino que evidenciaba que el cataclismo provocado por la ausencia de la "cabeza del reino" sometía a los actores sociales a la búsqueda de certidumbres y resoluciones políticas.

La crisis de autoridad, por un lado, otorgó la posibilidad de que las élites locales rioplatenses luchen por el control de las decisiones políticas y económicas y, por otro, habilitó una pugna entre jurisdicciones que se consideraban subordinadas a cabezas de Virreinato, Audiencia, Gobernaciones o Capitanías; es decir, cada jurisdicción aprovechó la crisis para recuperar y dirigir su autonomía. Solo como ejemplo, debemos considerar que las semanas siguientes a la instalación de la Junta Provisoria, algunas provincias la reconocieron y otras, como Montevideo, Paraguay, Charcas, Córdoba y Salta manifestaron sus desacuerdos.

En Buenos Aires, la lealtad monárquica asumió dos rumbos en 1810: aquellos que se definían como leales a la autoridad política organizada por la Casa Borbón y aquellos otros que asumían su lealtad guardando y conservando los derechos del Rey.

Ahora bien, debemos realizar la siguiente advertencia. La asunción del autogobierno y de la opción republicana no va a provocar inmediatamente la destrucción del imaginario regio, sino que este quedará disponible como un modo concreto de ejercer, pensar y estabilizar el poder. Se mantendrá -como indicamos más arriba- como una cultura y un modelo de acción de poder. La experiencia autonomista no va a destruir, en lo inmediato, dicho imaginario, porque el imaginario de la república y del autogobierno fue parte -y por momentos reivindicados, articulados y combatidos- del orbe conceptual y simbólico de la cultura borbónica. Sobre esta ambigüedad política y conceptual suscitada por imaginarios y vocablos resignificados, "superpuestos" y "cohabitantes", se van a desplazar la comprensión sobre los ejercicios del poder político. ${ }^{7}$

7 Una de las formas de construir esa representación fue, como en el caso del proceso de mayo de 1810, a través de un Petitorio Popular donde se consultaba acerca de los miembros de la futura Junta de Gobierno. 
Los insurgentes rioplatenses establecerán un momento autonómico y republicano, el cual se encontrará vinculado a las ciudades y a la mejor manera de administrar los asuntos públicos. Por lo tanto, el autogobierno y la administración de los derechos del Rey retrovertidos en la comunidad quedarán entrelazados en las propuestas insurgentes. Así, insurgencia, conservación de los derechos del Rey y administración autónoma de los mismos se articularían de manera singular en este proceso político.

Ante la necesidad de consolidar y amplificar el poder revolucionario, la Junta convocará a la elección de diputados para formular una constitución. De este modo, el poder político tiende a constitucionalizarse o, mejor dicho, la fórmula constitucional aparece como la mejor fórmula para construir un orden legítimo, estable y "extensivo".

La construcción de un nuevo orden y de una constitución legítima buscaba incorporar a actores sociales para ser conducidos y mandados. Entonces, las élites revolucionarias no sólo debían interpretar algunos intereses de la plebe y comunidades indígenas e incorporarlos en las instituciones, sino que debían realizar algunas de sus expectativas y constituirse en la interpretación y en voz de la ciudad. Perseguir el "Bien Común" y un orden estable obligaba a las élites rioplatenses a entablar y resolver algunas demandas de las plebes urbanas, rurales e indígenas ${ }^{8} \mathrm{y}$, a su vez, incorporarlas en la dinámica política, pero sin llegar a incorporarlas en la toma de decisiones estratégicas. Como indica Hilda Sabato, la incorporación fue ampliada pero de manera desigual. ${ }^{9}$ Por lo tanto, podemos observar que el autonomismo y su opción republicana politizó e incorporó distintos actores al proceso abierto con la crisis de la monarquía en 1808. Esta incorporación supuso nuevos interrogantes y problemas acerca de cómo organizar el orden político.

Las élites insurgentes apelaron a las memorias y representaciones del universo republicano, fundamentalmente clásico, buscando organizar el territorio y sus actores. De esta manera, se planteaba una perspectiva singular acerca de cómo estos actores pensaron la política y el territorio donde esta debía efectivizarse. En relación con esta perspectiva sobre la política y sobre el territorio, se construirán las diferencias con otros republicanismos. Por lo tanto, el problema fundamentalmente no radicaba en la intensidad o en la debilidad de las prácticas o instituciones representativas, sino en la concepción que se poseía de la política y de la comunidad. Por ejemplo, a partir de este planteo, se puede construir una diferencia significativa con el republicanismo norteamericano, el cual estructuraba su mirada y sus representaciones a partir de una voluntad popular que claramente estaba integrada por propietarios, recuperando de alguna manera los imaginarios de los republicanismos agrarios. Mientras el republicanismo iberoamericano se pensaba a partir de una voluntad popular realizada y materializada en la figura de la Ciudad o Pueblo, el norteamericano se centraba en la figura del yeoman. Por lo tanto, realizar los intereses de los propietarios era muy distinto a intentar realizar los intereses de habitantes propietarios y no propietarios de una ciudad. La prédica del bien común, en Hispanoamérica, suponía imaginar una propuesta jurídico-igualitaria en una comunidad jerárquica, corporativa y desigual. En este intento por la realización del bien común, como advertimos, se develará un haz de intereses convirtiendo a la Ciudad en una posibilidad ambivalente de unión o desunión, de cohesión y disolución.

8 Debemos considerar que la articulación y cohabitación de imaginarios niega cualquier planteo que considera que el imaginario republicano se ha desvirtuado. Ello implicaría la existencia de una tradición republicana o autonomista "pura" que se constituiría en un tipo ideal para evaluar distintas configuraciones políticas y lexicales..

9 Hilda Sabato, "Horizontes republicanos en Iberoamérica. Una perspectiva de largo plazo", en Entre la colonia y la república. Insurgencias, rebeliones y cultura politica en América del Sur, eds. Carmen McEvoy y Ana María Stuven (Lima: Instituto de Estudios Peruanos, 2007), 32. 


\section{Bajo los signos republicanos y monárquicos}

Como observamos, en el nombre del Rey los insurgentes emprendieron el autogobierno y en el intento de consolidarlo optaron por un léxico e imaginario republicano. De esta forma, el juntismo y la opción republicana estuvieron signadas por el nombre del Rey. Inclusive, la fórmula constitucional se pensó no sólo para limitar y regular autoridades, sino que se pensó para ser aceptada por el Rey ante su retorno. El Secretario de la Junta, Mariano Moreno, entendía que la constitución, la cual debía regular la elección de "un jefe de estas provincias", no debía "comprometer nuestro vasallaje al Sr. D. Fernando...". ${ }^{10}$

El vocabulario republicano, sus representaciones, sus nombres e, inclusive, sus figuras intelectuales, van a convivir y cohabitar con el nombre del Rey Fernando VII. Su nombre, recuperando una perspectiva pactista de la monarquía, se utilizará para revitalizar la capacidad de la comunidad de transferir poder o de administrarlo. Entonces, este vínculo de cohabitación o de convivencia de simbolismos y vocablos políticos configurará formas de pensar la política y la estabilidad del orden. El Rey tanto como el Pueblo, a través de sus autoridades, se podían pensar como figuras posibles a la hora de constituirse en "cabezas" de orden político. Si bien los estudios de Chiaramonte, Goldman así como de Ternavasio van a considerar el carácter significativo de la soberanía popular, no debe soslayarse la cultura borbónica, ni la presencia de la figura regia. Es decir, el Rey es una figura relevante en la cultura política y no puede desplazarse rápidamente. Esta situación daba cuenta de la fortaleza de los imaginarios monárquicos y borbónicos, así como su efectividad para suscitar imaginaciones o representaciones del ejercicio del mando. Las juntas intentarán convertirse en "cabeza de reino" supliendo la figura del Rey, recuperando el imaginario de una soberanía indivisible para organizar los territorios. Esta política abría una pregunta: ¿qué hacer con las soberanías locales?, ¿de qué modo incorporarlas en el nuevo orden?

Si bien la ciudad, en primer momento, pudo presentarse como una figura alternativa al cuerpo de la soberanía del Rey, ineludiblemente se buscó, en la realización de una constitución, la elección de un Jefe que pudiera resumir los distintos poderes. El Rey no solo debía ser sustituido por una jurisdicción, sino-bajo el carácter que sea- por otra persona que incorpore la dimensión cohesionadora y centralizadora del orden regio. La construcción de una comunidad política suponía la representación de las fuentes de soberanía (ciudades) y la elección de un Jefe. Es decir, no bastaba solamente con tener un cuerpo normativo ni con una idea -bastante compleja de ciudad — para sustituir la eficacia del poder monárquico.

Los órganos colectivos y su representación del Pueblo o de la Ciudad buscarán sustituir la figura y el mando del Rey. De esta manera, se abre un complejo dilema ante el vínculo entre opción republicana y el nombre del Rey; es decir, entre la apelación al Pueblo como sujeto de soberanía y el nombre del Jefe (o del nombre de una jefatura que "condensa" poder simbólico y político); o bien, entre el gobierno de las leyes establecido por los representantes de los pueblos y el gobierno del hombre (o de los hombres). En síntesis, se apela al nombre del Rey para constituir al Pueblo o la ciudad en sujeto soberano y, en ese momento, ambas figuras se afirman y vinculan. Por lo tanto, ambas figuras, Rey y Pueblo, son sujetos soberanos que se presentarán en la apelación de los partidarios del autogobierno: potestas populi y potestas regis. A partir de esta enunciación se abre el siguiente dilema: se presenta una soberanía apelando al

10 Gazeta Extraordinaria de Buenos-Ayres, 13 de noviembre, 1810. 
nombre de otra soberanía ausente y vacante, es decir, a la del Rey. Esto no sólo abre una tensión inherente entre el gobierno de las leyes y el gobierno de los hombres (y sus modos de obrar en el mando) que atravesará los procesos políticos americanos, sino que esa soberanía que apela a otra ausente para legitimarse — así como la tensión que esto supone- es apropiada y resignificada al interior de los discursos insurgentes.

La instalación del autogobierno y la lucha política por su legitimación logran que su apelación al Rey lo inscriban como figura habilitante. Por lo tanto, esto provocará que el nombre del Rey y su figura se inscriban, de alguna forma, en las experiencias autonomistas.

La Junta de Buenos Aires, ante la fragmentación del territorio que produjo la crisis monárquica, buscó subordinar a las diversas jurisdicciones que integraban el Virreinato del Río de la Plata. El temor a la fragmentación y los trastornos al interior de los gobiernos colegiados reactualizaron la búsqueda de figuras o fórmulas políticas que contengan la licuación territorial y cualquier posibilidad de formular pactos con el Consejo de Regencia, el Gobierno de Brasil o el mismísimo Napoleón. Para dar cuenta de esta preocupación, Manuel Belgrano en una carta dirigida al Cabildo de Asunción, indicaba que:

Estos dominios de nuestro desgraciado rey han de permanecer unidos, a pesar de las cábalas, intrigas e incidias de los mal intencionados; pues a más de clamar por ello los pueblos, se evita por ese medio el que caigan en manos de potencia extranjera o reconozcan la intruso rey de España Napoleón, como ha hecho algunas provincias, y que los mismo que eran vocales de la junta central, y formaron ese que se dice Consejo de Regencia, cuya autoridad ilegitima está circunscripta a Cádiz, y a esta horas tal vez no exista, o si existe, sea con el objeto de ver si pueden afianzar las Américas a las dominación napoleónica validándose de los arbitrios de que V.S., alucinado, ha echado mano. ${ }^{11}$

Para fines del año de 1810, la Junta de Buenos Aires no había logrado establecer un congreso ni una constitución. Tampoco había podido encontrar una fórmula política que organice un territorio asediado por los enfrentamientos bélicos.

1811 es un momento clave. Ese año se pone en evidencia la inviabilidad de un gobierno de muchos con la crisis de la Junta Grande. Se abre un periodo de lucha entre moderados y radicalizados que terminará en otra forma de centralización: el primer Triunvirato. Para caracterizar la disputa, podemos indicar que es una lucha por la conducción de la revolución; donde todavía no puede advertirse un debate entre los actores sobre la forma de gobierno. Los integrantes del Primer Triunvirato constituirán un elenco gobernante que tendrá un papel significativo en el debate sobre la independencia: Juan José Paso, Manuel Sarratea y Juan Martín de Pueyrredón.

Las diversas circunstancias políticas, entre las que debemos considerar las derrotas militares en el Alto Perú, Paraguay y la Banda Oriental, el ejercicio de la arbitrariedad, así como la crítica de las provincias al mando del Triunvirato por no reconocer sus intereses, erosionaron la autoridad de este. Estos descontentos, más una reconfiguración del escenario bélico, hacen que en octubre de 1812 el oficial José de San Martín y Alvear derroquen al Triunvirato e instauren a uno nuevo con Juan José Paso, Nicolás Rodríguez Peña y Antonio Álvarez Jonte.

11 Manuel Belgrano, "Al Cabildo de Asunción, 6 de diciembre de 1810, Costa sur del Paraná”, en Antecedentes de la independencia del Paraguay. Proclamas en Guaraní-Castellano del Gral. Belgrano, comp. Roberto Romero (Asunción: Servilibro, 2010), 82-83. 
Ante su debilidad social, el Segundo Triunvirato convocó a una asamblea constituyente para enero de 1813, intentando ampliar su base de sustentación y otorgar una nueva dinámica al poder territorial. En el Congreso del año XIII, no se deciden por una forma de gobierno, pero ello no implicará que no se expresen dos imaginarios sobre soberanía. Uno, representado principalmente por las élites políticas de Buenos Aires que reivindicaban una soberanía indivisible, la cual alentaba una gobernabilidad fuerte y central y otros, principalmente las élites autonomistas, que reivindicaban una soberanía plural y asociativa. Pero también esto implicaba dos maneras de comprender e imaginar una comunidad política: una, surgida y modelada por un poder central capaz de mantener, en un contexto de guerra, faccionalidad y descontento, un territorio cohesionado e integrado, y otra, surgida de las provincias como jurisdicciones autónomas que decidían libremente integrar y organizar un orden político (una reunión de provincias).

La Asamblea del Año XIII, pese a que se constituyó invocando la representación de las Provincias Unidas del Río de la Plata, ${ }^{12}$ no logró establecer un orden legítimo y aceptado por las diversas provincias, sobre todo las del Litoral y de la Banda Oriental, ${ }^{13}$ las cuales reclamaban un lugar privilegiado en establecimiento de una autoridad; por lo tanto, se abría un periodo de fragilidad política que, ante el recrudecimiento de la guerra, las élites de Buenos Aires reforzaron el poder ejecutivo y disolvieron la Asamblea. La contracara del momento asambleario y de su propia inviabilidad fue el nombramiento de un Director Supremo.

En la Asamblea del Año XIII, según Tulio Halperin Donghi, se presentaron algunas complejas situaciones que el poder revolucionario debió o buscó resolver: una, la disidencia del Litoral que se negaba a subordinarse a un poder central y otra, la inesperada marea de la Restauración europea, la cual si esta seguía avanzando, los dirigentes porteños podían verse enfrentados a una restauración de los Borbones, en cuyo nombre seguían gobernando ${ }^{14}$; por lo tanto, estas situaciones no permitieron dictar una constitución, ni declarar la independencia.

La lucha política al interior de la Asamblea y la desmesurada faccionalidad se resolvían a través de la concentración del poder en una persona. Entonces, podemos indicar que, desde 1810, las dos estrategias para consolidar y mantener el poder se moverán de manera pendular entre el momento asambleario y la concentración de poder en un centro y/o en una persona. Gobernar una revolución suponía varias miradas, sobre todo en un territorio atravesado por jurisdicciones que se afirmaban desde el autogobierno y, a su vez, por un territorio que todavía se autopercibía como la cabeza organizadora de este proceso; cosa que se fundamentaba en el ejercicio de ciudad cabecera y el propio rictus de la guerra que suponía la centralización.

\section{República, órganos colegiados y hombres fuertes}

Las convocatorias a congresos constituyentes y la elección de representantes para establecer un conjunto de normas y leyes se disolvieron ante las pugnas internas y la situación del enfrentamiento bélico. Inclusive, en términos concretos, el intento de constitucionalizar el poder a través de la convocatoria a asambleas o congresos no resultó efectivo para conducir los conflictos al interior de los cuerpos colegiados o entre jurisdicciones.

12 Artículo $1^{\circ}$ del "Inaugural Manifiesto de la Asamblea del año XIII", publicado en El Redactor de la Asamblea, no. 1, 27 de febrero, 1813.

13 Debemos indicar que el conflicto con el artiguismo -que había reconocido la autoridad de la Asamblea del Año XIII- se profundizará con la no aceptación de sus diputados por dicho órgano colegiado. No reconocimiento que en parte se fundamentara en que los diputados llevaban como mandato la declaración de la independencia y la instalación de un sistema confederal.

14 Tulio Halperin Donghi, Revolución y guerra. Formación de una élite dirigente en la Argentina criolla (Buenos Aires: Siglo XXI, 2005), 228. 
Como indicamos, la implosión territorial y política producida por la crisis imperial había reactualizado la disputa entre jurisdicciones y antiguas potestades, abriendo así una disputa por la manera de organizar políticamente los territorios y los nuevos centros de poder político. Inclusive, el pactismo habría un dilema a la hora de pensar la organización del poder, ya que las élites dirigentes rioplatenses se encontraban ante el planteo de organizarse con otras élites insurgentes a partir de considerarse en "pie de igualdad" y construir una soberanía a partir de la asociación de autogobiernos, o bien considerarse como "ciudad cabecera" o "cabeza de jurisdicción" sobre la cual debían articularse los demás centros de poder. De esta forma, si bien estas élites insurgentes apelaron al pactismo para impugnar a las autoridades coloniales, a la hora de organizar el poder la lógica pactista abría la posibilidad de licuar el poder de aquellas élites que entendían que los territorios debían organizarse desde una ciudad cabecera; es decir, la cultura borbónica que consideraba y reivindicaba un poder centralizado fue considerada por algunos como una modus y forma adecuada para organizar los territorios y contener la fragmentación. Entonces, el autogobierno de Buenos Aires que había fundamentado su autoridad política en el pactismo y en la apelación a la soberanía popular y que, además, esgrimían una política orientada hacia el bien común para ampliar su poder, se apropiaba de un modus operandi y modus vivendi de la cultura borbónica para responder a la licuación de la autoridad política.

El autogobierno y su opción republicana se tensionaba entre planteos que se desplazaban desde el federacionismo y el centralismo, abriendo de esta forma conflictos entre perspectivas que llevarían décadas más tarde a guerras internas.

En síntesis, la dinámica política y las pugnas internas impulsaron el fracaso de los cuerpos colegiados (cabildos, juntas, etc.) y se vieron obligados a apelar a formas organizativas, como triunviratos y directorios para clausurar prácticas que desagregaran el poder político y la virulenta faccionalidad. Entonces, podemos decir que la lucha por controlar el poder de la revolución fue la dimensión central que organizó los imaginarios que buscaban erigir un orden político.

Para no reducir este proceso a un conflicto entre Buenos Aires y las demás provincias, podemos advertir que ni las élites confederacionistas ni las élites centralistas lograron establecer un orden político aceptado e integrado territorialmente. La posibilidad del orden parecía atravesada por un "empate dramático".

Ahora bien, no solo había discusiones acerca de quién controlaba el proceso revolucionario y sobre la forma de organizar el poder político, sino que el ideal republicano introducía en las polémicas una lectura del "estado de las subjetividades", ya que una nueva comunidad política suponía crear un poder capaz de modelar actores. Entonces, la dirigencia insurgente y su opción republicana estarían sometidas a decisiones pragmáticas que buscaran reformar moralmente a la fuente misma del poder político (Pueblo) y, para ello, la política que las élites emprendieron articulaba representaciones pactistas y otras vinculadas a la cultura borbónica. Es decir, a veces las "viejas preocupaciones" podían diluirse o desterrarse con "viejas" formas de ejercer el mando. Pero esas "viejas" formas apropiadas por el orbe republicano asumían otras valencias y significaciones, por lo tanto, esas formas ahora presentes fueron atravesadas por la coyuntura y por la capacidad de los hombres de hacer cosas con modos, palabras y lenguajes. 
Como observamos, el enfrentamiento civil y, luego, la guerra independentista, tendrían como saldo la disgregación de los órganos colegiados y el surgimiento de figuras concentradoras y hombres fuertes. Estas figuras y dichos liderazgos deben rastrearse en las propias características forjadas por la crisis desatada por la Corona durante las reformas borbónicas y con relación a la formación de milicias y al establecimiento de nuevos poderes administrativos.

Para 1814, año de retorno de Fernando VII a su trono, se produciría una transformación en la guerra, porque el monarca ya no solo impugnaría las reformas gaditanas, sino que profundizaría el intento por recuperar el dominio americano. Por lo tanto, la guerra dejaría de plantearse como guerra civil para convertirse en independentista, ya que la posición de Fernando VII no dejaba espacio para negociaciones, ni siquiera para aquellos que no deseaban la independencia pero que soñaban con retener cuotas de autonomía.

Con respecto a la guerra, son importantes las consideraciones del Clement Thibaud sobre la misma. Si bien su estudio está vinculado al territorio grancolombiano, creo que presenta algunas de las claves para entender la dinámica de la guerra en el territorio del ex Virreinato del Río de la Plata. Según este autor, la guerra reforzaría la naturaleza territorial de las milicias y de los batallones patriotas, así como el carácter patricio o notable de la cadena de mando. ${ }^{15}$ Esto tendría, a nuestro entender, dos consecuencias: la primera, los liderazgos con una interlocución dinámica con sus milicias y las plebes urbanas y los indígenas afirmando su poder en los territorios que controlaban y la segunda, que dichos liderazgos se constituyeran en una representación política, como lo eran los órganos colegiados. Entonces, los liderazgos se convirtieron en una forma de representación y ejercicio del poder. Inclusive, cuando los órganos colegiados tuvieron serias dificultades para estabilizar el orden en diversas provincias, estos se presentaron como una superación real de dichas dificultades.

Estos liderazgos ocuparon de alguna forma, no sólo ese vacío de poder que había dejado la Corona y sus autoridades y que ahora lo experimentaban las experiencias de autonomistas colegiadas, sino que, además, se apropiaron al mismo tiempo de una propuesta republicana y de las memorias de ejercicio de poder efectivas, propias del mundo borbónico. Por lo tanto, esos liderazgos articularían el republicanismo clásico, el autogobierno y las formas decisionistas / centralistas. De esta forma, estos hombres de poder, que la tradición clásica republicana grecorromana observaba con cierta desconfianza, no se contrariaban con la opción republicana, sino que construían su liderazgo en relación con dicha propuesta. La opción republicana abrirá la posibilidad, entre los partidarios del autogobierno y de las autonomías provinciales, del surgimiento de jefes republicanos o de jefaturas republicanas.

Estos liderazgos no sólo promoverían, en algunos casos, ensayos constituyentes o autonómicos, sino que en otros momentos entendieron que sólo esos ensayos podían ser garantizados a partir de una forma del ejercicio del mando reunido en una sola persona o autoridad.

La realización de los intereses territoriales y la fragmentación que ello provocaba supuso una lucha entre diversos cuerpos, legitimidades y representaciones en la comunidad. Por lo tanto, los hombres fuertes, en algunos casos, pudieron ponerse por encima de los intereses de los cuerpos e intereses y reunirlos en una propuesta común. De esta forma, ejercían las formas de mando y de mediación que un gobernante supuestamente ecuánime habría utilizado. Por lo tanto, en ese significante Gobernante podría caber la figura del Rey, como

15 Clément Thibaud, "Ejércitos, guerra y la construcción de la soberanía: el caso grancolombiano", en La república peregrina. Hombres de armas y letras en América del Sur, 1800-1884, eds. Carmen McEvoy y Ana María Stuven (Lima: Instituto de Estudios Peruanos, 2007), 176. 
de Magistrado u otra. El vacío de la autoridad regia y las fantasías e imaginaciones que esto provocó impulsaron a los hombres a buscar un gobernante y un modo de gobierno, y en esa búsqueda, introdujeron como marca la tensión entre el gobierno de las leyes y el gobierno de los hombres. De alguna forma, esta tensión intentó "llenar" con diversas figuras y fórmulas ese significante gobernante.

\section{Travesías de la Independencia}

La guerra contra América iniciada por Fernando VII en 1814 no logró penetrar en los territorios del Río de la Plata; pero tampoco su Director Supremo, Gervasio Posadas, fue capaz de controlar el gobierno y las milicias. La guerra, por su carácter territorial, había consolidado actores y liderazgos que mantenían una relación pendular de autonomía/ heteronomía ${ }^{16}$ con respecto a Buenos Aires y enfatizaban una u otra postura ante determinadas coyunturas. A ello deberíamos añadir las jefaturas que la propia capital designaba para la dirección de la guerra.

Contener y dirigir los ejércitos se había vuelto esencial en un contexto de guerra, para demostrar efectividad en el mando político. La imposibilidad de llevarlo adelante obligó al Director Supremo a renunciar en 1815 y fue elegido a Carlos de Alvear en dicho cargo, el cual, como siempre sucedía, ante una lectura de una posible "anarquía" o tensiones con otras provincias, se apelaba a la concentración de poder. Lo interesante es que dicha forma tampoco garantizaba mantener el orden. Alvear no solo tendrá problemas con las milicias y líderes militares, sino también con el Cabildo de Buenos Aires. Como indica Tulio Halperin Donghi, Alvear no solo va a caer porque un grupo de oficiales se opone a su política, sino que en "parte es consecuencia de la misma concentración del poder", ${ }^{17}$ la misma que había sido la causa de su fuerza originaria.

La secesión propuesta por los artiguistas y la reorientación política hacia posiciones conservadoras van a llevar a las élites de Buenos Aires a plantear la necesidad de cerrar el "proceso revolucionario" -con lo cual, también quería decir poner entre paréntesis las políticas centralistas que el propio gobierno de Buenos Aires había llevado adelante desde 1810- y establecer un congreso que dicte constitución y forma de gobierno; decisión política que coincidía con la logia vinculada a San Martín, que frente al contexto de la restauración, presionaba por la declaración de la independencia. La promesa de cierre de la revolución y de establecer un vínculo con el interior leal a Buenos Aires volvería posible la institución del Congreso en la ciudad de Tucumán en 1816. De esta manera, la élite rioplatense debía contener la rebelión de algunas provincias (principalmente, Banda Oriental, Corrientes, Entre Ríos, Santa Fe), reforzar sus acuerdos con las restantes y establecer una figura ejecutiva que no se presentara como abusiva. Entonces, ante la licuación territorial y política, se instituyó una nueva asamblea; por lo tanto, el Congreso de Tucumán estuvo atravesado por una significativa fragilidad política y por una disputa real a la hegemonía bonaerense, la cual lentamente intentó modificarse con la alianza que Buenos Aires perseguía con algunas provincias para restar apoyos a la propuesta artiguista.

En relación con el contexto europeo y a la mirada de Europa sobre los acontecimientos rioplatenses, debemos considerar la sesión secreta del 6 de julio de 1816 del Congreso donde se convoca a Manuel Belgrano para que exponga un análisis sobre "el estado actual de la

\footnotetext{
16 En esta clave deben leerse las posiciones autonómicas de San Martín cuando es convocado desde Buenos Aires para reprimir al artiguismo o "poner" orden en otras provincias.

17 Halperin, Revolución y guerra, 232.
} 
Europa, ideas que ... en ella, concepto que ante las naciones de aquella parte del globo se había formado de la revolución de las Provincias Unidas y esperanza que estas podían tener de su protección" Los diputados preguntaron a Belgrano y este expuso lo que sigue: "Primero, que aunque la revolución de América en sus principios por la marcha majestuosa con que empezó había merecido un alto concepto entre los poderes de Europa, su declinación en el desorden y anarquía confirmada por tan dilatado tiempo, había servido de obstáculo a la protección... Segundo, que había acaecido una mutación completa de ideas en la Europa en lo respectivo a forma de gobierno: que como el espíritu general de las Naciones en años anteriores, era republicarlo ${ }^{18}$ todo, en el día se trataba de monarquizarlo ${ }^{19}$ todo ... Tercero, ... en su concepto, la forma de gobierno más conveniente para estas Provincias sería la de una Monarquía temperada; llamando la Dinastía de los Incas ... Cuarto, que el poder de España ${ }^{20}$ en la actualidad era demasiado débil e impotente por la ruina general a que la habían reducido las armas francesas, discordias que la devoraban y poca probabilidad de que el Gobierno Inglés le auxiliase para subyugarnos...", ${ }^{21}$ De esta manera, Belgrano comentaba la mutación política que se estaba realizando en Europa y lo incorporaba como una clave de lectura política para tomar futuras decisiones.

El Congreso de Tucumán, en sus inicios, poseía 33 diputados que representaban 14 provincias, incluidas Charcas. Se encontraban ausentes diputados de Paraguay, así como algunos miembros de la Banda Oriental, Entre Ríos, Corrientes y Santa Fe. Esta situación en parte expresaba:

Ni bien se instaló el Congreso Constituyente se desterró la idea de que se estaba formando un Gobierno Provisorio, como si aparecía en el Inaugural Manifiesto de la Asamblea del Año XIII, y se recuperó la lectura política que había realizado dicha asamblea sobre los "males" de la revolución, invocándose a "cerrad ya el periodo de la revolución y abrid la época de paz, y libertad y sed firmes en combatir a los agresores del interés público. ${ }^{22}$

Pese a la extrema fragilidad política, existía una voluntad política de declarar la independencia -sobre todo impulsada por San Martín y Manuel Belgrano-, dictar una constitución y establecer una gobernabilidad duradera. También el Congreso asumía la denominación de Provincia Unidas de Sud América remplazando a la denominación de Provincias Unidas del Río de la Plata, con lo cual se percibía la posibilidad de ampliar territorialmente la comunidad política. ${ }^{23}$

A su vez, en el Congreso en Tucumán, se encontraban presentes las memorias de proyectos de organizaciones anteriores, como aquello que proponía y suscitaba el nuevo contexto político. En esa articulación entre memorias y circunstancias presentes, se tejían las posibilidades de

18 Las cursivas son mías.

19 Las cursivas son mías.

20 Esta apreciación es diferente a la realizada en el año de 1814 donde la Asamblea General (del Año XIII) había autorizado al Director Supremo a tratar con la Corte Española. Efectivamente, el contexto europeo de 1816 imprime otras circunstancias.

21 Sesión secreta del 6 de julio de 1816, Tucumán, firmadas por Narciso Laprida, Boedo y Mariano Serrano, en Actas secretas del Congreso General Constituyente de las Provincias Unidas del Río de la Plata [1926] (Buenos Aires: Kraft, edición facsimilar).

22 Manifiesto Inaugural de la Asamblea del Año XIII, en El Redactor de la Asamblea, 27 de febrero, 1813

23 Esta denominación de Provincias Unidas de Sud América aparece: primero, en el proyecto redactado por la Sociedad Patriótica -la cual había promovido los conflictos de octubre de 1812 y pugnado por un congreso constituyente- para la Asamblea del Año XIII y que, como sabemos, quedó trunco; segundo, en un Proyecto de Constitución -transcripto por Emilio Ravignani, del cual se supone y así lo afirma Alberto Demicheli- que fue redactado por los diputados artiguistas inspirados en la Asamblea del Año XIII, pero que no llegó a discutirse, ya que los representantes no fueron aceptados. 
una nueva articulación política. En relación con las memorias de debates y polémicas de los años anteriores, quedaba claro que los órdenes pensados solo se habían "instituido en el aire" ya que la dinámica revolucionaria y la lucha por su control habían derruido cualquier posibilidad de conservación. A su vez, el contexto presente signado por la guerra y por el cambio de orientación de los sucesos europeos reactualizaban los debates sobre la soberanía monarquía -como lo plantea Belgrano- pero también sobre la legitimidad de un ejercicio de la forma de poder. La figura del monarca, tal cual la propone Belgrano, constituía un símbolo más amplio que la propia monarquía, sobre todo porque suponía una discusión sobre la forma del gobierno, sobre una idea de soberanía y sobre una manera de ejercer un poder que debía procurar la cohesión territorial; es decir, en un contexto deliberativo que no se privara de apelaciones a los vocablos del republicanismo clásico, la monarquía como modus operandi y como contrario a toda faccionalidad y "anarquía" que asumieran otra valencia simbólica y política. Nuevamente podríamos observar la cohabitación de vocabularios e imaginarios en el lenguaje de los actores.

El análisis de Belgrano - el cual en 1815 había intentado con Rivadavia erigir a un descendiente de los Borbones como rey de América del Sur- daba cuenta de la monarquización del mundo europeo y, por ello, asumía la necesidad de un régimen monárquico que surgiera de la dinastía incaica como forma de reparación e, inclusión, del mundo altoperuano y también, como podemos indicar, como una manera de encontrar un "punto de la historia" donde se mancilló una dinastía legítima y consentida por sus comunidades.

De esta manera, una propuesta de monarquía temperada o constitucional se presentaba en algunos actores como la mejor forma de articular una soberanía indivisible con cierta representación de las provincias. También, más allá de la consideración del rol de las soberanías provinciales en cada propuesta política, lo que había dejado la revolución de 1810 en el paisaje eran los actores empíricos referenciales (ciudades y provincias) y sus líderes locales que reclamaban el respeto por su autonomía y un lugar en la toma de decisiones. Más allá de las consideraciones sobre la revolución, quedaba claro que esta había instituido a actores que no serían tan fácilmente clausurados en la escena política.

\section{El Redactor: sesiones convulsionadas}

Antes de comenzar los debates propuestos por los diputados del Congreso Soberano, es importante realizar algunas consideraciones sobre El Redactor. Si bien no son las actas oficiales, allí están contenidos el resumen o la crónica de las sesiones, así como las opiniones de los redactores Cayetano Rodríguez (diputados por Buenos Aires) ${ }^{24}$ y Juan Molina (Secretario del Congreso), que vierten generalmente en el encabezado del diario. Además de su carácter descriptivo, entendemos que hay una búsqueda por forjar una mirada, es decir, poseen un afán performativo ya que apuesta a la construir de un análisis, pero también intenta provocar acciones que provoquen una nueva escena política.

Los integrantes de El Redactor apuestan a interpelar a las subjetividades, construir una pedagogía sobre los sucesos y sugerencias, facilitando un conjunto de saberes y citas que en su mayoría responden al vocabulario del republicanismo clásico. A su vez, ambos persiguen -algo que revolucionarios como Mariano Moreno habían intentado realizar- republicanizar

24 Cayetano Rodríguez posee una importante trayectoria política. Partidario de la revolución de 1810, amigo de Mariano Moreno y Director de la Biblioteca Pública (hoy Biblioteca Nacional). Junto a Juan Molina, comparten la condición de sacerdotes, lo que habla a las claras del intento de solidificar y profundizar una alianza con sacerdotes católicos que ya se habían iniciado con la revolución misma. También Rodríguez participó como miembro de la Asamblea del Año XIII y fue parte de la redacción de los diarios de sesiones de dicho cuerpo 
a los pueblos, modelar moral y políticamente a los sujetos de ese orden, construir una sentimentalidad cívica a través de un conjunto de saberes (antiguos, clásicos y modernos) y virtudes. Podemos decir que estos redactores expresan una perspectiva que intenta construir un vínculo entre "Ilustración" -presentada como tal por los autores, sin que ello suponga mecánicamente saberes modernos-y los pueblos.

La escritura de El Redactor, como el desarrollo del Congreso, se produce en un contexto de guerra, en una lucha entre provincias y facciones y en un cambiante escenario político europeo. Es decir, las sesiones y sus crónicas están guiadas por estos acontecimientos; así como por un conjunto importante de decisiones o indecisiones; es decir, la lógica de la representación no les permite sustraerse de los conflictos territoriales, ni de los avances y retrocesos de la guerra contra el poder español.

Los primeros actos del Congreso, el cual había comenzado a funcionar el 24 de marzo de 1816, son: primero que los diputados juraron "conservar y defender la Religión católica, apostólica y romana" y "promover todos los medios de conservar íntegro el territorio de las Provincias Unidas contra toda invasión enemiga"25 (juramento que queda oficializado en un formula), ${ }^{26} 2$ segundo que se establece una fórmula de juramento ${ }^{27}$ que debían realizar todas las autoridades legitimando y reconociendo como único Soberano al Congreso de Tucumán y tercero la elección del 3 de mayo del diputado por San Luis, Juan Martín de Pueyrredón, como Director Supremo. ${ }^{28}$

A su vez, debemos considerar que el mismo 24 de marzo — día en que se instala oficialmente el Congreso de las Provincias Unidas del Río de la Plata- son nombrados como Presidente al diputado Pedro Medrano (Buenos Aires) y como secretarios los diputados José Mariano Serrano (Charcas) y Juan José Paso (Buenos Aires), quienes no solo autorizarían actas, decretos, oficios y deliberaciones, sino que también plantearía, en los inicios, la búsqueda de Buenos Aires por hegemonizar este proceso.

Si nos detenemos en los primeros actos, encontramos algunas claves para entender la complejidad política que presentaba en el Congreso.

La gran preocupación sobre la integridad y unidad del territorio, como del reconocimiento de la Soberanía del Congreso, son los ejes nodales de los primeros actos y esfuerzos que van a atravesar y configurar a todo el proceso independentista. Esta preocupación supone la siguiente lectura y que El Redactor (no. 1) hace explícita:

La fuente de todos los males es la revolución". Frente a estos estragos habia que erigir un Congreso que establezca un gobierno que funcione como "dique poderoso" para "oponerse a este torrente de males politicos que amenazaban a absorber la patria, y

25 El Redactor del Congreso Nacional, no. 1, 1 de mayo, 1816.

26 El Redactor del Congreso Nacional, no. 1, 24 de marzo, 1816. “¿Juráis a Dios Ntro. Señor y prometéis a la Patria conservar y defender la Religión católica, apostólica y Romana? / ¿Juráis a Dios Ntro. Señor y prometéis a la Patria defender el territorio de las Provincias Unidas, promoviendo todos los medios importantes a conservar su integridad contra todas invasión enemiga? / ¿Juráis a Dios Ntro. Señor y prometéis a la Patria desempeña y legalmente los deberes anexos al cargo de diputados al Soberano Congreso, para que habéis sido nombrados"

27 Fórmula del Juramento que deben prestar al Congreso todas las Autoridades del Estado: “jJuráis a Dios nuestro Señor y prometéis a la Patria reconocer en el presente Congreso de Diputados la Soberanía de los Pueblos que representan?/ ¿Juráis a Dios nuestro Señor y prometéis a la Patria obedecer, guardar y cumplir, y hacer guardar y cumplir fielmente sus decretos y determinaciones? Si así lo hiciereis, Dios os ayude, y si no os lo demande"

28 El Redactor del Congreso Nacional, no. 4, 3 de mayo, 1816. 
sepultarla en sus ruinas" y "que salvase la unidad de las provincias, conciliase su voluntad, y reuniese los votos, concentrando en si el poder. ${ }^{29}$

Es decir, la unidad de la soberanías provinciales debían establecer un gobierno que concentrara poder político y que clausurase el ciclo revolucionario. La revolución había "convulsionado soberanías" instituyéndose como actores, lo cual -en ese momento- conspiraba con una unidad centralizada, pero también lo que conspiraba contra la unidad era la institución de poderes arbitrarios, particularmente erigidos o legitimados por el poder miliciano. En El Redactor puede leerse: "Una amarga experiencia os ha hecho ver la ineptitud del poder arbitrario, la inercia de la fuerza armada sin el apoyo de la autoridad reconocida unánimemente en los pueblos...".

Por lo tanto, los redactores reconocían que la afirmación y autonomía del poder de los territorios, así como la instauración de mandos arbitrarios con intenciones de soslayar dicha autonomía, no solo eran las "causa de todos los males" sino dos figuras o instancias que debían ser conjuradas. Entonces, a partir de esta lectura, eran llamados los diputados a construir un orden estable y una autoridad reconocida por los pueblos.

El Congreso, según la mirada de los redactores, tendrá como objetivo:

Establecer un poder sobre bases sólidas, y legales" y elegir un ciudadano para "llevar las riendas del gobierno con el tino politico que exigen las amargas circunstancias en que una providencia sabia, pero oculta, que debemos adorar, ha querido ponernos quizá para hacer más estimable el bien a que aspiramos... ${ }^{30}$

Por lo tanto, esta experiencia se devela como un laboratorio político que se configura a partir de la representación de los pueblos y donde se busca establecer presurosamente una dominación política y dictar una constitución. Para ello, buscará en la patria, en el "taller de los talentos", los saberes y los hombres para conducir este proceso.

En la sesión del 26 de abril, observamos que se propone acelerar el nombramiento del Director Supremo. En la sesión del 2 de mayo se decidió que al otro día sería la elección del Director Supremo quien sería el "único radical remedio de tantos males". ${ }^{31}$ Los diputados eligen al diputado de San Luis, Juan Martín de Pueyrredón, ${ }^{32}$ como Director Supremo. Los pueblos, a través de sus representaciones, eligen una figura de mando y delegan en este el proceso de unificación y estabilización del poder político y territorial. Por esta razón, en el mismo acto que eligen una autoridad suprema abren una tensión con las soberanías reunidas en el Congreso.

De esta forma, observamos que la asamblea no pudo prescindir de una figura que resumiera la "representación de las representaciones". Esto es interesante por dos cuestiones: primero, porque las soberanías jurisdiccionales reconocían que la comunidad y la ley no eran dimensiones suficientes para sustituir la figura o el cuerpo del Rey; así, la búsqueda de una figura que "encarne" el poder y mande era imprescindible. Segundo, un contexto de guerra

29 El Redactor del Congreso Nacional, no. 1, 1 de mayo, 1816.

30 Ibíd.

31 El Redactor del Congreso Nacional, no. 4, 2 de mayo, 1816.

32 Juan Martín de Pueyrredón, como Juan José Paso, se encontraban entre los sectores más radicalizados en el Buenos Aires de 1811. Integraron, con Manuel Sarratea, el Triunvirato. 
y de amenazas simbólicas y reales empujaba a formas de centralización o a elecciones de "hombres fuertes". De hecho, el mismo Director Supremo recibe, como se expresa en la sesión del 13 de mayo, la solicitud de dictar "medidas capaces de sofocar el germen de la división naciente" en la provincia de San Luis. ${ }^{33}$

La elección de un Director Supremo abría, desde el momento en que las representaciones eran concebidas como delegaciones de los territorios y a los cuales debía consultárseles permanentemente, una tensión difícil de erradir, ya que a dicha elección le otorgaban una "relativa autonomía" y decisión que los representantes de las provincias no deseaban o no podían garantizar. La lógica asamblearia se oponía, en el mismo momento de elección de un representante supremo, a una lógica desicionista/centralista, con lo cual abría un posible escenario de múltiples obstaculizaciones y tensiones. Estas tensiones no serían fáciles de saldar ya que la lógica asamblearia - autorreconocida como una asociación de pueblos- se sustentaba en un logro político/simbólico: y ese era haber constituido lo jurisdiccional como dimensión prexistente e integrarlo en la dinámica de la construcción de la soberanía y de representación. En ese sentido, la afirmación de la representación sujeta al territorio se tensionaba con la representación de una comunidad mayor o "nacional". Por lo tanto, el Congreso estaría sujeto a estas dos tensiones: imaginarios diversos sobre la soberanía y la representación. Pero también, esos imaginarios sobre la soberanía se debían, como plantea Chiaramonte, a lecturas diversas sobre los contractualismos. ${ }^{34}$ De esta manera, pese a que el Congreso se definía como Nacional, en la práctica se tensionaban imaginarios sobre la nación y sobre una imaginación de la misma.

A medida que se va desarrollando el Congreso comienza a develarse la tensión entre los diputados a la hora de construir una decisión común, como los conflictos que se producen en algunos territorios donde se cuestiona la legitimidad de los diputados elegidos. Por esta razón, puede observarse un conflicto larvado que pone en crisis las formas representacionales y expresa las luchas internas de las élites por integrarse a la decisiones que tome el Congreso. Entonces, tenemos una disputa entre imaginarios de representación política y, además, conflictos internos entre élites provinciales que erosionan la capacidad representacional de ciertos diputados. También comienza a observarse la presión de ciertos actores políticos para la instauración de una constitución de un Estado libre e independiente; ${ }^{35}$ situación que va erosionando cualquier seguridad o perspectiva de instauración de una orden durable.

En la sesión del 19 de abril, los redactores citaban lo siguiente, alentando a los diputados a declarar la independencia: "Nosotros (decían en cierta ocasión los valientes americanos del norte reunidos en Congreso, y dispuestos a resistir a todo trance al poder británico) hemos calculado los costos, y nada encontramos tan terrible como una voluntaria esclavitud". ${ }^{36} \mathrm{El}$ proceso independentista iniciado por el Congreso intentó negociar con Artigas y las provincias que representaba (Santa Fe, Corrientes, Entre Ríos y Misiones) y con un Paraguay que había consolidado su soberanía con respecto al poder de Buenos Aires y a la Península Ibérica. Ambos territorios se mostraban como la contracara de propuestas de poder en construcción: la propuesta federal artiguista y la confederal de Paraguay.

\footnotetext{
33 El Redactor del Congreso Nacional, no. 5, 13 de mayo, 1816.

34 Chiaramonte, José C., Nación y Estado en Iberoamérica. El lenguaje político en tiempos de las independencias (Buenos Aires: Sudamericana, 2004), 134.

35 El Redactor del Congreso Nacional, no. 3, 26 de junio, 1816.

36 El Redactor del Congreso Nacional, no. 3, 19 de abril, 1816.
} 
La presión por la declaración de la independencia suscitó una polémica sobre la forma de gobierno y, especialmente, sobre la forma de gobierno que se consolidaba en Europa. En El Redactor del 25 de julio de 1816 se indicaba que "la ambición desmedida mudó lastimosamente " $^{37}$ el ideal del gobierno monárquico en tiranía, y debiendo el que nace rey proveer a todos, solo quería ser proveído y servido de todos; su administración declinó a veces en despotismo absoluto, el respeto real en idolatría, y la regalía se desvaneció en humos de divinidad." ${ }^{88}$ Por lo tanto, la degradación había dejado al mundo sin "autoridad" y sus formas de ejercicio. En este sentido, entendemos que no se trata de una nostalgia monárquica, sino de un principio o modus que garantizaba la cohesión del orden y que clausuraba el deseo de todos los sujetos por querer mandar los unos sobre otros.

Es interesante observar como la "convulsión de soberanías" es comprendido como una lectura sobre las subjetividades frente al poder. En este sentido, El Redactor se preguntaba:

¿Qué avanzan los pueblos con sacudir el yugo opresor de un déspota, si van a caer en manos de otros tantos, cuantos abusan de la libertad sin ley, y en consecuencia sin limite, que traten de dominarlos? ¿Ignoran que esta es la aspiración del común de los hombres? ¿Se les oculta que roto el freno de una obediencia reglada, cada uno se piensa acreedor al mando que en otros abomina? ¿Se han olvidado que cada hombre tiene dentro de símismo las simientes de este error desde que todos en nuestro padre común desobedecimos a Dios?... Cada uno quisiera ser independiente, y todos apetecen ser reyes después que se desvaneció el proyecto de ser Dioses. ${ }^{39}$

A partir de esta perspectiva, podemos decir que la ruptura del orden anterior había desatado todas las pasiones de dominio que habitaban en los hombres y que hasta ahora nadie había podido regular. Ahora, el Congreso, según la opinión de El Redactor, debía erigir una soberanía y un orden que contuvieran dichas pasiones y no permitieran conflictos provinciales que cuestionaran al Congreso Soberano. El descontento frente a esta situación fue manifestada por El Redactor ante los sucesos de La Rioja:

¿Con que hay derecho en los pueblos para hacer revoluciones a su antojo a la faz del soberano congreso, instalado y reconocido? ¿Hay derecho para vivir sin ley, sin freno $y$ sin respeto a las autoridades constituidas, quitar y poner gobierno, defiriendo al capricho y descontento de cada ciudadano? ¿Y hay en las Provincias Unidas hombres que autoricen y promuevan sistemas tan desgreñados y excesos de esta clase, confundiendo el uso de la libertad con el abuso espantoso de los derechos que ella concede a los pueblos? Si los hay, he aqui nuestras desgracias y el origen de nuestros males. ${ }^{40}$

Así, los redactores sugerían que existiese algo de la dinámica de poder que ponía en cuestión la posibilidad de establecer reglas comunes y construía la imagen de un Congreso asediado por diversos poderes. De esta forma, este órgano colegiado va a intentar desalentar y disciplinar a aquellos liderazgos militares y políticos que lo pueden debilitar. Ante ello, $E l$ Redactor indicaba que:

\footnotetext{
37 Las cursivas son mías.

38 El Redactor del Congreso Nacional, no. 5, 25 de julio, 1816.

39 El Redactor del Congreso Nacional, no. 5, 25 de julio, 1816

40 El Redactor del Congreso Nacional, no. 5, 9 de mayo, 1816
} 
La militar defensa de un estado es un operación exclusiva de las armas; pero su organización lo fue siempre de las luces. Éstas sin aquellas harán un estado imbécil; aquellas sin éstas lo harán monstruosamente informe. ${ }^{41}$

Las luces -aquellas que articulan los saberes de la política- deben vincularse a las milicias para conducirlas y deben vincularse a ellas para que defiendan el orden que dichas luces formulan.

A fines del mes de mayo, según El Redactor del Congreso Nacional del 23 de agosto de 1816, se presentan los temas centrales que debía definir el Congreso. Éstos fueron planteados por los diputados Esteban Gascón (Buenos Aires), Teodoro Sánchez de Bustamante (Jujuy) y José M. Serrano (Charcas) en la "Nota de las materias de primera y preferente atención para las discusiones y deliberaciones del Soberano Congreso". Entre ella se indicaba:

1. Un manifiesto que exponga a la consideración de las provincias los espantosos males, que han causado las divisiones de los pueblos, y las revoluciones fraguadas en el ardor de las pasiones...

2. Declaración, o deslinde de las facultades del actual Soberano Congreso nacional constituyente, y tiempo de su duración.

3. Discusiones sobre la declaración solemne de nuestra independencia politica: el manifiesto de dicha declaración...

4. Pactos generales de las provincias y pueblos de la unión, preliminares a la constitución, y que en la circunstancias se estimen necesario para consolidar dicha unión.

5. Que forma de gobierno sea más adaptable a nuestro actual estado, y más conveniente para hacer prosperar las provincias unidas.

6. Decretada la forma, un proyecto de constitución...

14. Demarcación de territorio; creación de ciudades y villas.

16. El repartimiento de terrenos baldios; aplicación o venta de las fincas de temporalidades a beneficio de la agricultura y aumento de los fondos del estado. La arreglada distribución d a los naturales en plena propiedad de las tierras de comunidad. ${ }^{42}$

La Nota de estos diputados establecía como prioridades la declaración de la independencia, el establecimiento de una forma de gobierno y la realización de una constitución, convirtiéndose los propósitos inmediatos que intentarían resolver.

El Redactor ${ }^{43}$ comentaba que, en el mes dejulio, se acordó como primer asunto la "independencia del país". Los "diputados en sala plena, aclamaron la INDEPENDENCIA de las Provincias Unidas de Sud América de la dominación de los reyes de España y su metrópoli". La votación fue unánime. La declaración diría lo siguiente: "Que es voluntad unánime e indubitable de estas provincias romper los violentos vínculos que las ligaban a los reyes de España, recuperar los derechos, de que fueron despojados, e investirse del alto carácter de nación libre e independiente del rey Fernando 7, sus sucesores y metrópoli".

41 El Redactor del Congreso Nacional, no. 6, 23 de agosto, 1816.

42 El Redactor del Congreso Nacional, no. 6, 23 de agosto, 1816.

43 Ibíd. Aunque en este número se comentan las sesiones de mayo, se anticipa e introducen los sucesos de la declaración de independencia. 
El 19 de julio se acordó la fórmula del juramento:

¿Juráis por Dios N. Señor y esta señal de la cruz, promover y defender la liberta de las Provincias Unidas en Sud-América y su independencia del Rey de España Fernando 7, sus sucesores y metrópoli, y toda otra dominación extranjera? ¿Juráis a Dios N. Señor y prometéis a la patria el sostén de estos derechos hasta con la vida, haberes, y fama? Si así lo hiciereis Dios o ayude, y si no, él y la patria os hagan cargo. ${ }^{44}$

Ahora bien, esa fórmula fue discutida y ampliada por los diversos diputados, ya que se habían manifestado algunas voces que presionaron para reformular el texto. En la sesión secreta del 19 de julio de 1816, "tomando la palabra el Señor Medrano ${ }^{45}$ pidió que se había de pasar al Ejército el acta de Independencia, y la fórmula del juramento de ella, después de las expresiones de sus sucesores, y Metrópoli, se agregase, y de toda otra dominación extranjera, dando por razón que de este modo se sofocaría el rumor esparcido por ciertos hombres malignos de que el Director del Estado, el General Belgrano, y aun algunos individuos del Soberano Congreso, alimentaban ideas de entregar el País a los portugueses, y fue acordado." ${ }^{46}$

Estas sospechas poseían algún fundamento empírico y tenían que ver con que tanto Belgrano, como Rivadavia -es decir, Buenos Aires- habían intentado en el año 1815 negociar la instalación de una monarquía con Carlos IV.

La búsqueda de legitimidad y reconocimiento de la independencia advertía sobre la capacidad de presión de algunos actores y sobre la necesidad de gobernar las palabras para no suscitar sospechas. Es así que la búsqueda de apoyos y seguridades se volvía imperiosa.

En relación con la búsqueda de adhesiones, en la sesión del 29 de julio, se determinó que de las 3000 actas de la independencia que se iban a imprimir, 1500 se imprimieran en castellano, 1000 en quichua y 500 en aymara; ${ }^{47}$ apuntando así recuperar la preminencia simbólica en el Alto Perú.

Ante la declaración de la independencia, El Redactor refuerza el lenguaje republicano. El 5 de septiembre de 1816 podía leerse:

Hacer felices las repúblicas, esto es, decía Cicerón, el trabajo y la obra de los que las dirigen. Nunca habrán conseguido realizarlo sino cuando presenten a la faz del mundo unos pueblos que unidos y enlazados entre sí con los vinculos de una fraternidad perpetua bajo un genio tutelar que sepa conservarla, estudien en regla su conducta por las leyes que imperan la sobriedad, la buena fe, la racional diferencia a la autoridad, la honesta industria, el trabajo y la virtud. ${ }^{48}$

Ahora declarada la independencia, había que formular una comunidad política duradera y precaverse de que a la "libertad que ha aspirado, venga a serle al fin una deidad cruel..." 49

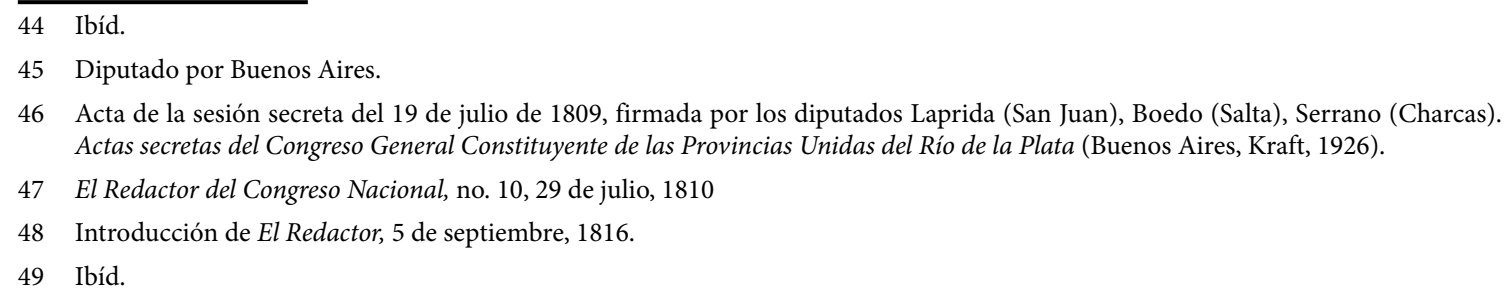


Nuevamente, los redactores volvían a Cicerón para advertir aquella cita que indicaba: "No hemos nacido para nosotros, sino para la república".

Estas apelaciones al lenguaje republicano, sus valores y promesas se develan de manera trágica, ya que no podían contener el frenesí revolucionario que "transforma a los seres irracionales, haciéndoles probar todos los furores de las pasiones más humillantes y atroces" ${ }^{50}$

Ante la pregunta acerca de qué hacer o cómo conducir dichas pasiones desmesuradas, se presentan diversas respuestas: una, establecer un orden y autoridades regidas por una ley surgida con el acuerdo de las diversas soberanías y otra, erigir un orden establecido "desde arriba" por una voluntad que se encuentre y ordene dichas soberanías. Por lo tanto, ambas respuestas sobre cómo organizar el poder se orientaban hacia la formulación del modo de gobierno.

Exactamente tres días después de la declaración de la independencia, el mismo 12 de julio se insiste en la necesidad de avanzar sobre la forma de gobierno. El diputado por la provincia de Catamarca, Manuel Antonio de Acevedo, expresó por "su parte que esta fuese una monárquica temperada en la dinastía de los Incas y sus legítimos sucesores, designándose desde que las circunstancias lo permitiesen para sede del gobierno la misma ciudad de Cuzco...". ${ }^{51}$ Frente a esta postura, se alzaría otra que se expresó en la sesión del 15 de julio, donde "el diputado P.Oro, ${ }^{52}$ exponiendo que para proceder a declarar la forma de gobierno, era preciso consultar previamente a los pueblos, sin ser conveniente otra cosa por ahora, que dar un reglamento provisional; y que en caso de procederse sin aquel requisito a adoptar el sistema monárquico constitucional, a que veía inclinados los votos de los representantes, se le permitiese retirar del Congreso, declarando ante quien debía verificar la renuncia de su empleo".$^{53}$

Entre las posturas esgrimidas de los diputados Acevedo y de Oro, se entretejía la trama de tensiones y perspectivas que se articulaban en torno al debate sobre la soberanía. Es decir, para el diputado Oro, el Congreso debía consultar nuevamente con sus representados reivindicando la soberanía última de la comunidad; mientras los que apoyaban la postura de Acevedo suponían que esa posición negaba no solo el carácter soberano del Congreso, sino que ponía en duda una idea de representación vinculada a una de soberanía indivisible. Para estos la postura de Oro hacía inviable un Congreso sometido al furor de la guerra. A su vez, esta discusión instalaba el interrogante sobre el ejercicio de la decisión: ¿esta debía surgir de acuerdos entre los representantes o los pueblos? Ineludiblemente, circunscribir la decisión en los pueblos suponía plantear cierta desconfianza por la representación, la cual se fundamentaba en la variedad de conflictos que en algunas provincias se producían entre los Cabildos y sus representantes.

En la sesión del 19 de julio

pidió la palabrael diputado Serran $0^{54}$, yhabiendo analizado las ventajase inconvenientes de un gobierno federal, que aseguro había deseado para estas provincias, creyéndole el mas a propósito para su felicidad y progresos, añadió que en la actualidad, después

50 Ibíd.

51 El Redactor del Congreso Nacional, no.10, 12 de julio, 1816.

52 Diputado por la Provincia de San Juan.

53 Ibíd., 15 de julio, 1816.

54 Diputado por Charcas. 
de una seria reflexión sobre las circunstancias del país, la necesidad del orden y la unión, la rápida ejecución de las providencias de la autoridad que presida la nación, y otras conversaciones, creía conveniente la monarquía temperada, que conciliando la libertad de los ciudadanos y el goce de derechos principales que se reclaman por los hombres en todo país libre con la salvación del territorio en lo lamentable de la presente crisis, traía envuelta en si una medida convenientísima al mismo objeto, que expondría oportunamente... ${ }^{55}$

A su vez, "el señor Acevedo ${ }^{56}$ renovó su moción para que se adoptase la forma monárquica en la dinastía de los Incas...". ${ }^{57}$

La propuesta de una monarquía temperada o constitucional -alentada por la mayoría de las élites de Buenos Aires, Belgrano, San Martín y otras provincias- se oponía a una posición federal minoritaria pero que tenía como amenaza el orbe artiguista. De esta manera, se fortalecen imaginarios centralista, que apostaban por reconstruir y conducir los territorios desde una soberanía indivisible -establecida por dicho Congreso-y los imaginarios federales que entienden en la articulación asociativa para el establecimiento del orden y de la unidad.

Lo más llamativo de los partidarios de la monarquía temperada no solo era la reactualización de los modus regios, ni la necesidad de articular la monarquía con el sistema representativo para la estabilización del orden; sino que apostaban a establecerla en un territorio que las milicias independentistas no controlaban eficientemente. Cuzco se presentaba como el "tercero de la concordia": ni Buenos Aires, ni en las Provincias interiores.

La monarquía temperada o constitucional se erigía como la mejor respuesta a la convulsión de soberanías y el modus operandi de la monarquía se volvía eficaz para ello. Se presentaba como la "última ratio" para organizar un orden.

Los debates continuaron y en la sesión del 20 de julio se "oyeron las exposiciones de algunos señores diputados, que llenando el tiempo destinado a esta sesión, presentaron los unos la cuestión de la problemática con los motivos que los detenían para no decidirse por la monarquía temperada, a pesar de las ventajas o menos inconvenientes que ofrecía con respecto a las demás; y opinaron otros por su positiva conveniencia, atendiendo al estado y circunstancias del país, y por comparación a los bienes y males que todas ellas respectivamente presentan. $Y$ no decidiéndose cosa alguna, terminó la sesión". ${ }^{58}$

La indecisión y la tensión comienzan a atravesar un Congreso que solo se legitima por haber declarado la independencia. El otro dato político es que ese mismo día comienzan a presentarse resistencias colectivas a la propuesta de monarquía temperada o constitucional, lo cual provocaría una nueva insistencia de los "monárquicos". En la sesión del 31 de julio, "tomó la palabra el diputado Castro, ${ }^{59}$ y renovando la discusión sobre la forma de gobierno, pronunció un prolijo razonamiento en favor del monárquico constitucional, por haber sido el que dio el Señor a su antiguo pueblo, el que Jesucristo instituyó en su iglesia, el más favorable a la conservación y progreso de la religión católica, y el menos sujeto a los males

\footnotetext{
55 Ibíd., 19 de julio, 1816.

56 Diputado por Catamarca

57 Ibíd.

58 Ibíd., 20 de julio, 1816.

59 Diputado por La Rioja
} 
políticos que afectaban ordinariamente a los otros; sostuvo las ventajas del hereditario sobre el electivo, y las razones de política que habían para llamar a los Incas al trono de sus mayores, despojados de él por la usurpación de los reyes de España. Añadió a estas razones otras el diputado Rivera, ${ }^{60}$ en un abundante discurso, cuyo argumento fue persuadir que era un actor de necesidad, de conveniencia y justicia adoptar la forma monárquica, temperada bajo la dinastía de los antiguos Incas.[...] Se intentó realizar una votación y un conjunto de diputados se opusieron" ${ }^{61}$

El 5 de agosto se volvió sobre la discusión acerca de la forma de gobierno. El presidente Jose Ignacio Thames ${ }^{62}$ "haciendo mérito del principio de derecho, que prescribe la restitución al poseedor y dueño de lo que se le despojó por violencia, dedujo la que a los Incas debían hacérsele de la dominación que se les usurpo por los soberanos de España". El diputado Araoz, también de la ciudad de Tucumán, indicaba que no podía establecerse una dinastía dominante si todavía no estaba convenida la forma de gobierno. Por su parte, el diputado Serrano, representante de Charcas, advertía cuatro inconvenientes políticos que podía suscitar el restablecimiento de la dinastía incaica. "Primero, porque esta misma idea promovida no ha mucho tiempo por Pumasagna en el Cuzco, lejos de haber obrado el efecto que ahora se asegura de alarmar los naturales en favor de la independencia del país, lo produjo contrario rindiendo el Cuzco los mismos de quienes se esperaba que halagados de su atractivo la sostuviesen. 2 por los males que inevitablemente debían temerse de la regencia interinaria que forzosamente debía establecerse. 3 por las crueles divisiones que moverían los pretendientes con el influjo sobre las parcialidades de los naturales del territorio que se anegaría en la sangre de las diversas familias aspirantes al trono. 4 por las dificultades que presentaba la creación de la nobleza o miembros que hubiesen de formar el cuerpo intermedio entre el pueblo y el trono: deduciendo de todo esto que la confianza debía fijarse únicamente en la organización de una fuerza armada capaz de contrarrestar la del enemigo...". ${ }^{63}$ De esta manera, Serrano ubicaba, a diferencia de anteriores opiniones, la prioridad en la creación de una fuerza armada, desechando cualquier propuesta que restituyera en el poder a la dinastía incaica. Se podría especular que representaba el imaginario que las élites altoperuanas poseían sobre las comunidades indígenas.

Un día después, se "renovó inmediatamente la discusión sobre la forma de gobierno. El señor Anchorena ${ }^{64}$ formó un discurso político, exponiendo los inconvenientes del gobierno monárquico, haciendo observar las diferencias que caracterizaban los llanos y altos del territorio, y el genio, habitudes y costumbres de unos y otros habitantes, decidiéndose la mayor resistencia de los llanos a la forma monárquica de gobierno, y por la imposibilidad moral de conformar unos y otros bajo la misma forma y gobierno que se adoptase para los de las montañas; concluyendo con que a vistas de las dificultades que estas diferencias ofrecen, el único medio capaz de conciliarlas, era, en su concepto, el de la federación de provincias. Se detuvo en manifestar la conveniencia de esta forma de gobierno, y termino la sesión". ${ }^{65}$ A partir de este discurso, podía observase que entre las élites políticas bonaerenses existían posiciones que alentaban la construcción de una federación y que la fundamentación no estaba sujeta, explícitamente a la reivindicación de las autonomías provinciales, sino a partir

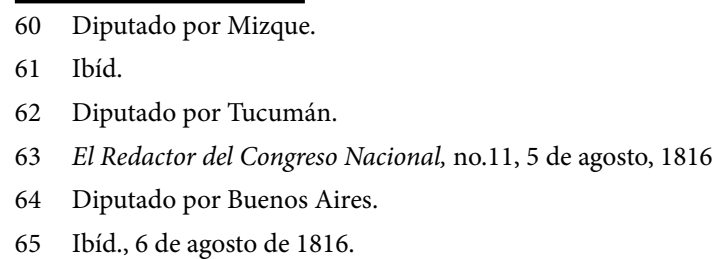


de las características de los climas y geografías de los diversos territorios que integraban las Provincias Unidas.

En noviembre de 1816, El Redactor se pregunta: “¿Cuál de los gobiernos es mejor?" “Entretanto nuestra indecisión en adoptar un gobierno impugnándolos todos, arroja de sí la idea de que queremos ninguno". ${ }^{66} \mathrm{El}$ análisis de los redactores expresaba la incapacidad del Congreso, el cual, ante esta situación, seguía manteniendo de "manera insuficiente" las figuras de la Asamblea, como la del Director Supremo. Ambas, en tanto no se forjará una determinación, las transformaba en "barcos a la deriva".

La faccionalidad, la guerra y el debate sobre las formas de gobierno en dicho contexto colocan a los partidarios del momento republicano a buscar en la propuesta monárquica una salida a la ingobernabilidad. Los republicanos van a echar mano sobre los imaginarios monárquicos para clausurar el furor revolucionario. Los partidarios de la opción republicana que habían apelado a la retroversión de los derechos del monarca y al nombre del mismo para constituir y fundamentar los ensayos autonómicos en Buenos Aires, ahora en su mayoría recurrían a la monarquía para salvar "esa opción asediada".

El pesimismo y desencanto político va ir ganando la postura de los redactores. El Redactor del 21 de noviembre de 1816 advertía que "la expresión macedonio en la boca de Alexandro fue suficiente para reducir a su deber a un ejército furioso, sublevado y sin freno. Que desgracia! Sólo el nombre de americanos no hace la impresión que debiera en los habitantes del Sud", ${ }^{67}$ es decir, ese adjetivo identitario no poseía ninguna fortaleza porque la comunidad política que se había pensado en establecer se encontraba en crisis; en una crisis profunda donde la disputa política no permitía formas de negociación, acuerdo y dominación de una postura sobre otra. Dicha situación quedaría expresada por los redactores cuando indicaban que "Nuestros peligros y contrastes, ni por graves ni por repetidos han sido suficientes para extinguir el ardor delas mutuas rivalidades, destructores de la paz, de la seguridad y de las dulzuras de la vida social? Porque trabajamos en labrar nuestra ruina, cuando corremos ansiosos tras las felicidad y la gloria? Pensamos dar al mundo político el nuevo fenómeno de un estado erigido sobre las bases de la división y la discordia?". ${ }^{68}$

\footnotetext{
66 El Redactor del Congreso Nacional, no.12, 14 de noviembre, 1816.

67 El Redactor del Congreso Nacional, no.12, 14 de noviembre, 1816.
}

68 El Redactor del Congreso Nacional, no.19, 24 de septiembre, 1816. 


\section{CONCLUSIÓN}

En el texto podemos observar las polémicas que se suscitaron en las primeras semanas luego de la declaración de la independencia. Dichas polémicas integran la novedad de un mundo europeo que cambia y, por otro lado, reactualiza las tensiones que se formularon sobre la representación, la soberanía y el ejercicio del mando en los inicios de la Revolución de Mayo (1810).

El Congreso de Tucumán, como lo hizo la Asamblea del Año XIII, logra establecer una figura -el Director Supremo- que represente a las soberanías provinciales y concentre poder, pero con el transcurso de los acontecimientos su mando se diluirá ante la lucha de intereses y ante las disputas prácticas que alientan concepciones diversas de la representación y la soberanía. En relación con la representación, se abre un profundo dilema entre dos concepciones: unos que apelan a una idea de representación vinculada a la jurisdicción y que reniegan de cualquier autonomización y otros que alientan una idea de representación que entiende que debe existir un momento de autonomía de los representantes con respecto a sus representados para tomar decisiones. En este último caso, la representación se define por la capacidad de fundar el momento autónomo y decidir los destinos de la totalidad de los territorios. Estamos ante la tensión de los que afirman una representación jurisdiccional (a la cual debe volverse para consultarla) o una representación nacional que asuma el destino de la comunidad política más allá de la jurisdicción de la que provenga el representante.

Por último, como podemos comprobar, una lógica federal va a enfrentarse a una lógica centralista que encontrará en la monarquía temperada la solución a la licuación territorial y política. Pues bien, la monarquía no solo representaba la mutación del contexto europeo, sino también un modus operandi del poder político que hundía sus raíces en el legado borbónico. Es un modus que permite pensar la organización y dinámica del poder y que advierte sobre la capacidad de ciertos hombres de poder concentrar o resumir el poder en momentos de crisis.

\section{FUENTES}

Acta de la sesión secreta del 19 de julio, 1809, firmada por los diputados Laprida (San Juan), Boedo (Salta), Serrano (Charcas).

El Redactor del Congreso Nacional, no. 1, 1 de mayo, 1816.

El Redactor del Congreso Nacional, no. 3, 19 de abril, 1816.

El Redactor del Congreso Nacional, no. 4, 2 de mayo, 1816.

El Redactor del Congreso Nacional, no. 5, 25 de julio, 1816.

El Redactor del Congreso Nacional, no. 6, 23 de agosto, 1816.

El Redactor del Congreso Nacional, no. 10, 19 de julio, 1816.

El Redactor del Congreso Nacional, no. 11, 6 de agosto, 1816.

El Redactor del Congreso Nacional, no. 12, 14 de noviembre, 1816.

El Redactor del Congreso Nacional, no. 13, 21 de noviembre, 1816.

El Redactor del Congreso Nacional, no. 19, 24 de septiembre, 1816.

Gazeta Extraordinaria de Buenos-Ayres, 13 de noviembre, 1810. 
"Inaugural Manifiesto de la Asamblea del año XIII", en El Redactor de la Asamblea, no. 1, 27 de febrero, 1813.

Carta de Manuel Belgrano al Cabildo de Asunción, 6 de diciembre, 1810, Costa sur del Paraná.

Sesión secreta del 6 de julio, 1816, Tucumán, firmadas por Narciso Laprida, Boedo y Mariano Serrano.

\section{REFERENCIAS}

Actas secretas del Congreso general Constituyente de las Provincias Unidas del Rio de la Plata. Buenos Aires: Kraft, edición facsimilar, 1926.

Belgrano, Manuel. "Al Cabildo de Asunción, 6 de diciembre de 1810, Costa sur del Paraná". En Antecedentes de la independencia del Paraguay. Proclamas en Guarani-Castellano del Gral. Belgrano, comp. Roberto Romero (Asunción: Servilibro, 2010), 81-83.

Chiaramonte, José C. Nación y Estado en Iberoamérica. El lenguaje político en tiempos de las independencias. Buenos Aires: Sudamericana, 2004.

Goldman, Noemi. "Formas de gobierno y opinión pública o la disputa por la aceptación de palabras, 1810-1827". En La vida política en la Argentina del siglo XIX. Armas, votos y voces, comp.Hilda Sabato y Alberto Lettieri. Buenos Aires: Fondo de Cultura Económica, 2003.

Halperin Donghi, Tulio. Revolución y guerra. Formación de una élite dirigente en la Argentina criolla. Buenos Aires: Siglo XXI, 2005.

Quijada, Monica. “La potestas populi: una revisión del pensamiento político hispánico y la Modernidad". En Entre la colonia y la república: insurgencias, rebeliones y cultura política en América del Sur, comp.Beatriz Bragoni y Sara Mata. Buenos Aires: Prometeo, 2008.

Romero, Roberto. Antecedentes de la independencia del Paraguay: proclamas en Guarani-Castellano del Gral. Belgrano. Asunción: Servilibro, 2010.

Sabato, Hilda. "Horizontes republicanos en Iberoamérica. Una perspectiva de largo plazo". En Entre la colonia y la república: insurgencias, rebeliones y cultura política en América del Sur, comp. Beatriz Bragoni y Sara Mata. Buenos Aires: Prometeo, 2008.

Thibaud, Clément. "Ejércitos, guerra y la construcción de la soberanía: el caso grancolombiano". En La república peregrina: hombres de armas y letras en América del Sur, 1800-1884, eds. Carmen McEvoy y Ana María Stuven. Lima: Instituto de Estudios Peruanos, 2007.

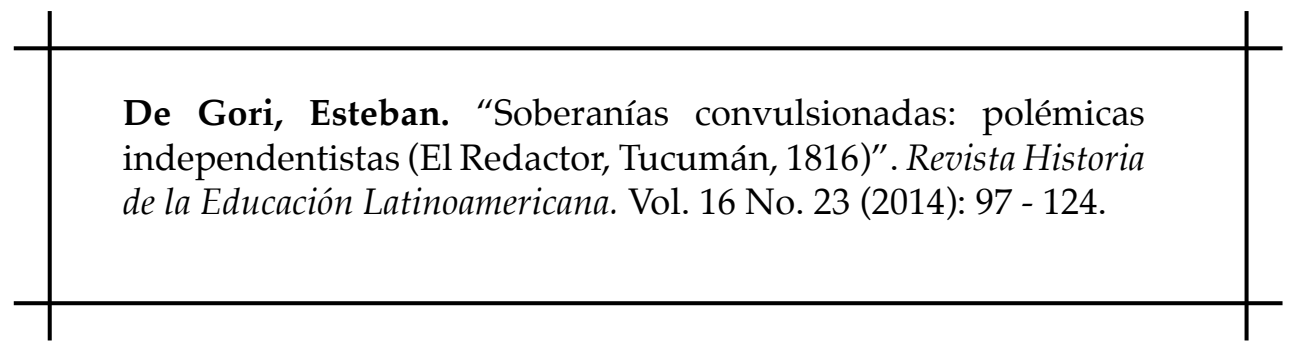




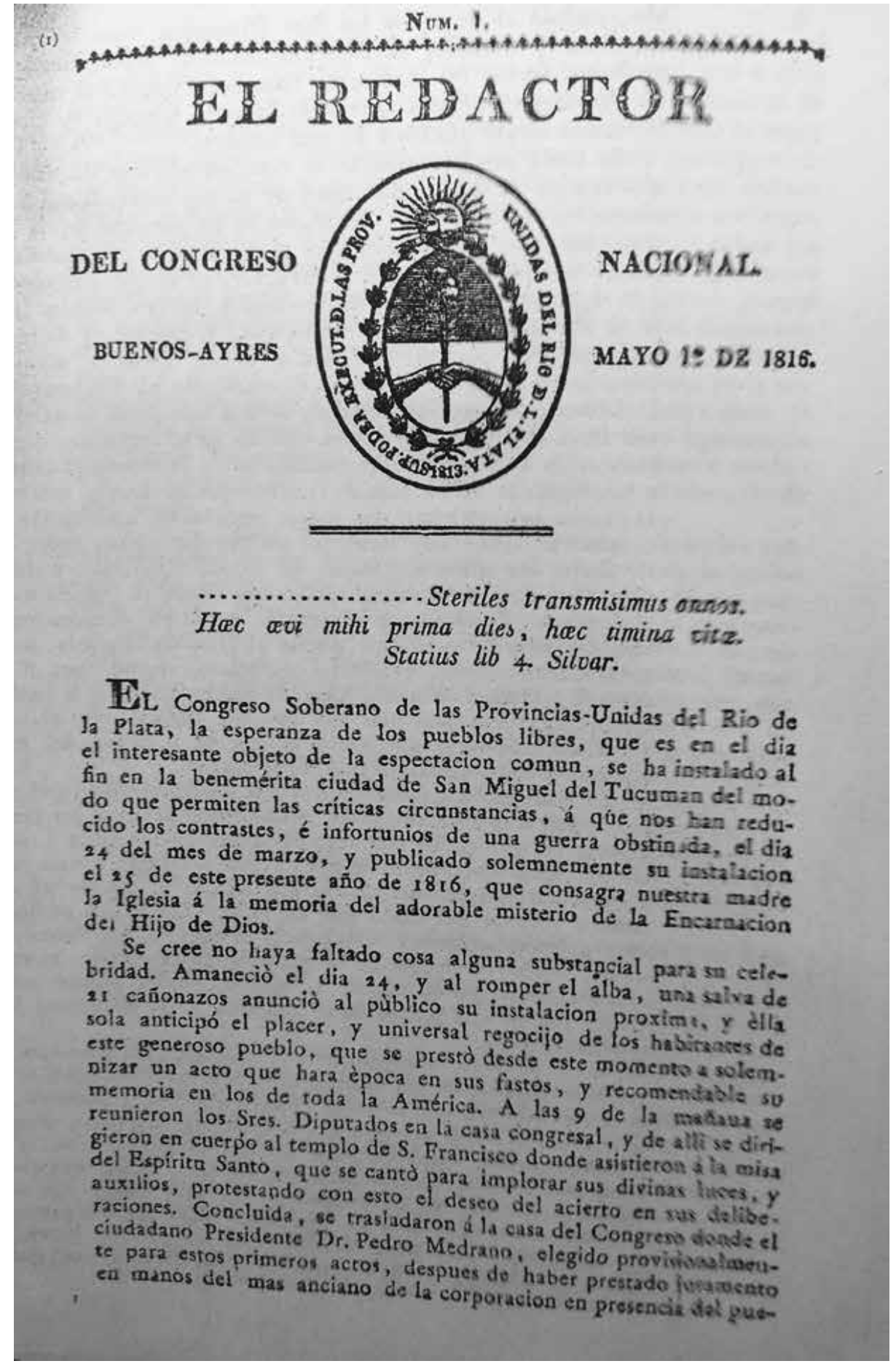

